\section{Inhibitory Activity against Angiotensin I-Coverting Enzyme of Peptides Originating from Fish and Shellfish Muscle*1}

Kunio Suetsuna, ${ }^{* 2}$ Masahiro Yamagami,*2 and Kazumasa Kuwata*2

(Received February 18, 1988)

Food proteins are changed into small peptides by digestive enzymes and some of the resultant peptides were found to have physiological activities.1) We have observed in vitro inhibitory activity against angiotensin I-converting enzyme (EC 3.4.15.1) of basic peptides originating from the muscle of sardine and hair tail ${ }^{2)}$ and in vivo blood pressure lowering and vasodilatory effects of these peptides. ${ }^{3)}$ In this paper we report the inhibitory activity against angiotensin I-converting enzyme and the amino acid compositions of muscle peptides from 12 kinds of fish and 3 kinds of shellfish.

Five hundred grams of various fish and shellish muscles were homogenized in $1 l$ of deionized water. Ten grams of pepsin (EC 3.4.23.1, Merck Co.) was added to the homogenates whose $\mathrm{pH}$ had been adjusted to 2.0 with $1 \mathrm{~N}-\mathrm{HCl}$, and the mixtures were incubated for $20 \mathrm{~h}$ at $37^{\circ} \mathrm{C}$ with stirring. After the incubation, the reaction mixtures were immediately subjected to ultrafiltration through Diaflo-membrane of type YM $10(\phi 76 \mathrm{~mm})$. The filtrate was applied to a column $(4.2 \times 15 \mathrm{~cm})$ of Dowex $50 \mathrm{~W}-\mathrm{X} 4(50-100$ mesh, $\mathrm{H}^{+}$form) cation exchange resin. After the column was washed sufficiently with deionized water

\section{Short Paper}

to remove some impurities, the desired peptides were eluted with $2 l$ of $2 \mathrm{~N}-\mathrm{NH}_{4} \mathrm{OH}$. After being concentrated to $100 \mathrm{~m} /$ under vacuum, the eluate was applied to a column $(2.5 \times 150 \mathrm{~cm})$ of Sephadex G-25 (medium). Required fractions were collected and concentrated to dryness to give peptide powder.

Inhibitory activity against angiotensin I-converting enzyme was measured as previously described. ${ }^{2)} \mathbf{I D}_{50}$ value was defined as $\mathrm{mg}$ of peptide powder, when enzyme activity was reduced by $50 \%$. Peptide $(10 \mu \mathrm{g})$ was hydrolyzed with $200 \mu l$ of $6 \mathrm{~N}-\mathrm{HCl}$ in an evacuated sealed glass tube for $24 \mathrm{~h}$ at $108^{\circ} \mathrm{C}$. Amino acid analyses were performed on a PICO-TAG TM amino acid analyzer (Waters Associates). ${ }^{4}$ The inhibitory activity (ID $)_{50}$ and amino acid compositions of the fish and shellfish peptides are shown in Table 1. ID values of sardine and skipjack peptides were lower than those of the others. Amino acid analyses showed that fish peptides were rich in aspartic acid, glutamic acid, arginine, proline, isoleucine and lysine and that shellfish peptides were rich in aspartic acid, glutamic acid and lysine, Isolation of these peptides and determination of their amino acid sequences are under investigation.

\section{References}

1) H. Chiba and M. Yoshikawa: Kagaku to Seibutsu, 25, 396-405 (1987).

2) K. Suetsuna and K. Osajima: Nippon Suisan Gakkaishi, 52, 1981-1984 (1986).

3) K. Suetsuna: Hakko to Kogyo, 46, 179-182 (1988).

4) D. R. Koop, E. T. Morgan, G. E. Tarr and M. J. Coon: J. Biol. Chem., 257, 8472-8480 (1982).

Table 1. Inhibitory activity $\left(\mathrm{ID}_{50}\right)$ against angiotensin I-converting enzyme and amino acid compositions ${ }^{* 1}$ of fish and shellfish muscle peptides

\begin{tabular}{|c|c|c|c|c|c|c|c|c|c|}
\hline Fish name & $\left(\mathrm{ID}_{50}\right)^{* 2}$ & ASP & GLU & SER & GLY & HIS & ARG & THR & PRO \\
\hline $\begin{array}{l}\text { Black porgy } \\
\text { Skipjack } \\
\text { Marlin } \\
\text { Pacific mackerel } \\
\text { Jack mackerel } \\
\text { Flounder } \\
\text { Spanish mackerel } \\
\text { Atka mackerel } \\
\text { Flying fish } \\
\text { Sting ray } \\
\text { Sardine } \\
\text { Hair tail } \\
\text { Pearl oyster } \\
\text { Blue mussel } \\
\text { Little clam }\end{array}$ & $\begin{array}{l}68.7 \\
29.6 \\
59.1 \\
56.7 \\
48.2 \\
54.4 \\
84.9 \\
66.5 \\
53.3 \\
63.4 \\
27.1 \\
56.6 \\
28.8 \\
45.4 \\
31.0\end{array}$ & $\begin{array}{l}6.87 \\
7.68 \\
6.38 \\
8.34 \\
6.51 \\
7.02 \\
9.02 \\
8.47 \\
8.02 \\
7.38 \\
9.68 \\
9.89 \\
12.8 \\
14.6 \\
12.7\end{array}$ & $\begin{array}{r}7.85 \\
8.14 \\
7.50 \\
9.40 \\
8.38 \\
10.37 \\
9.76 \\
9.43 \\
11.37 \\
10.01 \\
15.31 \\
9.26 \\
16.3 \\
16.4 \\
14.7\end{array}$ & $\begin{array}{l}2.62 \\
3.09 \\
2.63 \\
4.43 \\
3.24 \\
2.34 \\
2.19 \\
2.33 \\
2.68 \\
3.37 \\
2.56 \\
2.58 \\
5.6 \\
5.3 \\
4.9\end{array}$ & $\begin{array}{l}5.67 \\
5.64 \\
4.78 \\
5.51 \\
4.74 \\
3.95 \\
2.88 \\
4.03 \\
4.90 \\
5.15 \\
2.39 \\
3.17 \\
6.1 \\
5.7 \\
5.3\end{array}$ & $\begin{array}{l}2.22 \\
3.51 \\
4.50 \\
2.21 \\
2.04 \\
4.28 \\
2.50 \\
2.15 \\
2.26 \\
2.42 \\
3.02 \\
2.94 \\
1.7 \\
1.4 \\
1.3\end{array}$ & $\begin{array}{l}8.12 \\
7.90 \\
7.09 \\
8.92 \\
6.93 \\
8.91 \\
8.26 \\
7.11 \\
7.89 \\
8.02 \\
6.85 \\
6.13 \\
7.4 \\
6.9 \\
6.4\end{array}$ & $\begin{array}{l}1.65 \\
3.15 \\
2.48 \\
2.46 \\
3.10 \\
2.56 \\
2.08 \\
1.87 \\
2.98 \\
2.88 \\
2.97 \\
2.74 \\
5.5 \\
4.6 \\
4.3\end{array}$ & $\begin{array}{r}7.14 \\
7.76 \\
9.94 \\
10.14 \\
7.72 \\
8.73 \\
6.88 \\
6.98 \\
7.48 \\
6.54 \\
5.57 \\
5.22 \\
2.3 \\
2.8 \\
2.3\end{array}$ \\
\hline Fish name & ALA & TYR & VAL & MET & CYS & ILEU & LEU & PHE & LYS \\
\hline $\begin{array}{l}\text { Black porgy } \\
\text { Skipjack } \\
\text { Marlin } \\
\text { Pacific mackerel } \\
\text { Jack mackerel } \\
\text { Flounder } \\
\text { Spanish mackerel } \\
\text { Atka mackerel } \\
\text { Flying fish } \\
\text { Sting ray } \\
\text { Sardine } \\
\text { Hair tail } \\
\text { Pearl oyster } \\
\text { Blue mussel } \\
\text { Little clam }\end{array}$ & $\begin{array}{l}4.07 \\
3.42 \\
3.11 \\
3.48 \\
4.55 \\
3.02 \\
2.91 \\
2.13 \\
2.67 \\
2.43 \\
2.05 \\
1.87 \\
6.1 \\
6.4 \\
5.9\end{array}$ & $\begin{array}{l}1.42 \\
1.74 \\
1.69 \\
0.90 \\
1.17 \\
1.53 \\
1.40 \\
1.53 \\
1.58 \\
1.83 \\
1.53 \\
0.98 \\
4.2 \\
4.3 \\
4.0\end{array}$ & $\begin{array}{l}3.20 \\
2.75 \\
3.94 \\
3.01 \\
1.02 \\
1.98 \\
1.05 \\
1.84 \\
1.65 \\
1.76 \\
1.76 \\
1.90 \\
4.9 \\
4.4 \\
4.1\end{array}$ & $\begin{array}{l}1.65 \\
1.67 \\
2.00 \\
3.11 \\
2.76 \\
2.07 \\
1.15 \\
2.31 \\
1.09 \\
2.03 \\
1.08 \\
1.23 \\
1.1 \\
1.4 \\
1.1\end{array}$ & $\begin{array}{l}0.89 \\
0.65 \\
0.65 \\
0.82 \\
1.08 \\
0.42 \\
1.05 \\
1.84 \\
0.91 \\
0.70 \\
1.23 \\
0.66 \\
0.8 \\
0.7 \\
0.6\end{array}$ & $\begin{array}{r}6.09 \\
5.91 \\
5.82 \\
6.27 \\
6.89 \\
7.38 \\
5.61 \\
6.46 \\
7.23 \\
5.98 \\
6.32 \\
8.03 \\
10.9 \\
9.3 \\
8.6\end{array}$ & $\begin{array}{r}7.39 \\
8.47 \\
6.50 \\
9.65 \\
6.89 \\
7.42 \\
6.38 \\
7.99 \\
10.62 \\
9.27 \\
8.33 \\
8.42 \\
6.9 \\
7.4 \\
6.9\end{array}$ & $\begin{array}{l}1.26 \\
1.49 \\
1.72 \\
0.71 \\
0.93 \\
0.90 \\
0.79 \\
0.67 \\
0.90 \\
0.78 \\
0.62 \\
0.44 \\
3.1 \\
3.5 \\
3.2\end{array}$ & $\begin{array}{c}31.89 \\
27.03 \\
29.27 \\
20.64 \\
31.39 \\
27.12 \\
36.09 \\
34.39 \\
25.79 \\
29.45 \\
28.73 \\
36.54 \\
9.5 \\
10.0 \\
9.4\end{array}$ \\
\hline
\end{tabular}

-1 Expressed as $\mathrm{g} / 100 \mathrm{~g}$ of peptides.

*2 Expressed as $\mathrm{mg}$ of peptides when angiotensin I-converting enzyme activity was reduced by $50 \%$.

*1 魚貝類筋肉由来ペプチドのアンジオテンシンI変換酵素阻害能について。

*2 Department of Food Science and Technology, Shimonoseki University of Fisheries, Yoshimi, Shimonoseki, Yamaguchi 759, Japan (末網邦男, 山上雅弘, 桑田和昌：水産大学校製造学科). 